\title{
Declaration Effect of Cash \& Stock Dividends on Share Price: An Empirical Study on Dhaka Stock Exchange
}

\author{
Md Lutfor Rahman ${ }^{1}$, Mohammad Ruhul Amin ${ }^{2}$, Md. Noman Siddikee ${ }^{3}$ \\ ${ }^{1 \& 2}$ Department of Business Administration, Northern University Bangladesh, Bangladesh \\ ${ }^{3}$ Department of Business Administration, International Islamic University Chittagong, Bangladesh
}

\begin{abstract}
This study analyzes the impact of different types of dividend declaration, namely stock and cash dividends. Using event study method, MAAR and CAAR, this study found no evidence of abnormal returns on the declaration day for either of the types of dividends. However, significant negative returns are reported on days prior to the declaration day for stock dividend, indicating speculative nature of the investors. Furthermore, it provides positive returns during the post-announcement period as the investors realize the chance of potential gains. However, as far as cash dividend is concerned companies listed under DSE do not provide any significant abnormal returns during the 60 days event window. For CAAR, no significant return is reported for cash dividend, while stock dividend provided a maximum 5.6\% abnormal returns during the post announcement period.
\end{abstract}

JEL Classification Code: M41; M49

\section{INTRODUCTION}

C ORPORATIONS declare dividend for the benefit of its shareholders. They may either declare cash dividend or stock dividend. As it is with the objective of the corporations to increase the share holders' wealth, they declare dividend as a part of the income to them beside capital gain they achieve through appreciation of the prices of their stocks. When cash dividends are given the share holders directly benefit from the cash income as part of their cash income after taxes are deducted from it. On the other hand when stock dividends are declared the shareholders of a company may keep the shares and hope that the company will be able to utilize the money not paid out in cash dividend to earn a better rate of return in the future. They may also sell some of their new shares to create their own cash dividend which are basically tax exempted.

However, as a result of the dividend declaration, the question arises on its effects on the capital gain (or loss) measured by the share price appreciation (or depreciation). The earlier studies on Dhaka Stock Exchange found that dividend does not add values to the investors as far as cumulative returns are concerned. However, studies done by previous authors did not distinguish the effects between cash and stock dividends. Study done by Rahman \& Amin (2009) on DSE found that positive returns are reported prior to the dividend announcements irrespective of the nature of the dividends due to speculative trading and insider information regarding the announcements. Using the Cumulative Average Abnormal Returns (CAARs) attributed to the announcement the study also concluded that the investors loss up to $7 \%$ of their invested capital. The authors also recognized that the returns are highly volatile around the announcement date and suggested a study may be conducted to analyze if the declaration of stock dividend in isolation results in any gain to the investors.

The dividend irrelevancy hypothesis proposed by Modigliani and Miller (1961) suggests that dividend does not have any impact on the value of the companies. However, the studies done on many markets around the globe show mixed findings. This study is aimed to identify whether stock dividends has more impacts on the share prices than that of the cash dividends using the data of a promising emerging market- DSE.

\section{EMPIRICAL EVIDENCE AROUND THE GLOBE: A SURVEY OF THE EXISTING LITERATURES}

A good deal of studies has been undertaken on both the developed and the developing countries. The impacts of cash and stock dividends on the share price returns have been mixed in those markets. These findings to a great extent either support the dividend irrelevancy theory or provide other explanations for the reasons of the dividends declared. A summary of those findings may include the followings.

Yu Qiao et al (2001) found a positive statistical relationship between the dividends and mix dividend policies of firms on the stock market. However the study found the market was not sensitive to cash dividend.

Wei Chen et al (1999), Empirically analyzed the dividend policy of the companies listed in shanghai stock market by using cumulative abnormal return (CAR). It tried to see whether there is any evidence of existence of the signaling effect of dividend policy in this market and also to find its characteristics, if exists. This study showed that the degree of CAR was very much different arising as a result of different dividend policies. The CAR of right issue was found to be higher than that of cash dividend 
but lower than that of the bonuses.

Louis T. W. Cheng, Hung-Gay Fung \& T. Y. Leung (2006), found that in many emerging financial markets, firms typically pay stock dividends rather than cash dividends. They found Chinese investors appear to favor stock dividend over cash dividends [Chen, Firth, and GAO (2002)]. There are many hypotheses explaining why firms pay out stock dividends. The signaling and retained earnings hypotheses, which are found closely linked and to relate stock dividends to a firm's good growth or investment potential, appear to be the leading contenders in explaining stock dividend policies of firms in the U.S. [Baker, Phillip's, and Powell (1995)].

Kalay and Loewenstein (1985) and Nissim and Ziv (2001) found a strong positive relationship between dividend changes and a firm's ability to generate future earnings and cash. Other writers showed that a dividend loses its information content in explaining firm's future performance when earning and earning related variables (such as earnings forecast) are released simultaneously [Conroy, Eades, and Harris (2000); Mikhail, Walther and Willis (2003)]. A new view is the tunneling perspective, which argues that cash dividends may be used as a tool to re-direct firm resources to benefit large shareholders and top management at the expense of minority shareholders [Faccio, Lang, and Young (2001)]. Studies also provided some evidences for various hypotheses on stock dividend issue. In an examination of responses from chief financial officers, Eisemann and Moses (1978) show support for the signaling, liquidity, cash substitution, and retained earnings hypotheses. Baker and Philiphs (1993) report the evidence from a manager survey for the signaling and retained earning hypotheses.

Therefore, the retained earnings hypothesis argues that stock distributions of less than $25 \%$ are a signal of future earnings as the stock dividend-paying firms are expected to replenish the retained earnings account with future earnings. Empirical evidence for the retained earnings hypothesis is mixed [Chottiner and Young (1971); Banker, Das, and Datar (1993); Peterson, Millar, and Rimbey (1996)].

Cash dividends and stock dividends have been argued substitutes for one another. As discounting a dividend payment would likely produce a negative market reaction, firms usually issue stock dividends rather than paying out cash dividends that might lead to a cash shortage for internal use. Ghosh and Woolridge (1985) find that issue of stock dividends can mitigate the negative market reaction due to reduction or omission of cash dividends, which provides evidence for the cash substitution hypothesis.

Modiglian and Miller (1961) argued that dividend policy has no effect on either the price of a firm's stock or its cost of capital, in a perfect world, the dividend policy is irrelevant to shareholders wealth. This proposition has laid solid theoretical foundation for the dividend policy. After that, economists have offered explanations for dividend declaration in different ways including such effect as taxes, dividend signaling, agency cost issues and transaction cost.

Foster and Vickrey (1978) report that stock dividend issues generate positive abnormal returns on the declaration date rather than on the ex-date and that the size is not a determinant of market reaction, which primarily supports signaling function of stock dividends.

Black, Fischer (1976) found that, In addition to cash dividend and stock dividend, several mixed types of dividend payment are given apart from cash dividend and stock dividend such as mix of bonus issues and dividend, mix of rights issues and dividend.

Fung and Leung (2001) proved that reinvestment by plowing back earnings should be viewed positively; it is a good investment approach if there are profitable opportunities in firms. If firms indeed have good investment prospects, shareholders prefer stock dividends in order to preserve cash for investments; seasoned equity financing is not readily available for future funding needs because of regulatory constraints. Thus the underdevelopment of china's financial market implies that rational Chinese stockholders would generally prefer stock dividends to cash dividends. However, in contrast, Huang and fung (2004) found that if dividend policy serves as a signal to the market, firm value (price) will change as a result. Price appreciation will not translate into financial gains for the controlling stockholders whose shares cannot be traded through the stock exchanges. Thus, they would prefer cash dividends to realize an immediate financial gain.

Therefore, from the above literature we would find that the firms pay out dividend both in cash and stock and there are several hypotheses explaining the reasoning for the preference of the type of dividends. Those hypotheses are Signaling Effect Hypothesis, Retained Earning Hypothesis, Tunneling Hypothesis, Liquidity Hypothesis or Cash Substitution Hypothesis, Tax Effect Hypothesis, Agency Cost Hypothesis, and Transaction Cost Hypothesis.

\section{Data Collection and Methodology}

\subsection{SAMPLE DESIGN AND DATA COLLECTION:}

The study is based upon a sample of 16 firms which declared only stock dividend and 23 firms which declared only cash dividend for the period of 1 January 2007 to 31 December 2007. The reason for choosing the year 2007 as the sample of the study is that it is considered to be one of the most stable years in the political history of Bangladesh which more often than not influence the stock market and other macroeconomic variables of the country. The date of dividend announcement was collected from www.biasl.net and the data on the stock prices were collected from the DSE archive. A list of the selected companies together with their announcement dates and rate of dividend declared has been provided under appendix A1. 


\subsection{Selecting the EVEnT Window:}

For an event study selecting the right window is very important as other variables might affect the dependant variable concerned if the window is too long in duration. On the other hand, if the window is too short, the effect of an event may be incomplete. For the present study the authors have considered 61 days event window appropriate for analysis. For the study the returns on the announcement day, returns on 30 days prior to the announcement day, and returns on 30 days after the announcement have been considered for analyzing the $\mathrm{cu}$ mulative average abnormal returns.

\subsection{RESEARCH DESIGN}

\subsubsection{Calculating the Abnormal Return}

Different methods have been used to calculate the abnormal return resulted from an announcement. The literature on the methodology for event study suggests various approaches for analysis. Some discussions may be found in Bodie, Kane and Marcus (2005), Campbell, lo, and MacKinlay (1997). These methods may be summarized as, firstly the Constant Mean Return Model (CMRM), which assumes a firm's average stock return as constant over time. The method does not allow for general market movement. Secondly Market Adjusted Return Model (MARM) which is also called the index model assumes each firm has some average return and risk characteristics as the market as a whole. And lastly the Economic Models such as CAPM and APT. Using any economic models provide very similar results to the market model. (Campbell, Lo, Mackinlay, 1997).

The methodology here has been used as suggested by Bowman (1983), Brown \&Warner (1980 \& 1985), Kritzman (1994), Mackinlay (1997), and Saens, Sandoval (2005). In general, our objective is to find out whether there exist any abnormal returns attributed to the dividend declaration. Therefore, the general format for calculating the abnormal returns may be as-

$$
A R_{i t}=R_{i t}-E\left(R_{i t} / \Omega_{t-1}\right)
$$

Where, $A R_{i t}, \quad R_{i t}$, and $E\left(R_{i t} / \Omega_{t-1}\right)$ are the abnormal, actual, and normal return for time $t$, respectively. $\Omega$ is the conditional information set in period $t$. Index Model or the Market-Adjusted Return Model (MAAR) is used as the normal return representing $E\left(R_{i t} / \Omega_{t-1}\right)$ for the present study. We have tried to minimize the other factors from affecting both the return on the prices of individual stock and the market returns. Since the percentage change in market price is deducted from the percentage change in the price of the individual share on the respective days, the remainders shows the unsystematic portion of the value change of a particular stock resulted from dividend announcement. The following formula is used to calculate the market adjusted abnormal returns:
$M A A R_{i t}=R_{i t}-R_{m t}$
.......2

Where,

$M A A R_{i t}$ is the market adjusted abnormal return for security i over the time $t . \mathrm{R}_{i t}$ is the return on security $i$ on time $t$, calculated as $\left(\mathrm{P}_{i t}-\mathrm{P}_{i t-1}\right) / \mathrm{P}_{i t-1}$, where, $\mathrm{P}_{i t}$ is the market closing price of stock $i$ on day $t \& \mathrm{P}_{i t-1}$ is the market closing price of stock $i$ on day $t-1 . \mathrm{R}_{m t}$ is the return on the DSE all share price index at time $t$, calculated as $\left(\mathrm{I}_{t}-\mathrm{I}_{t-1}\right) / \mathrm{I}_{t-1}$, Where $\mathrm{I}_{i t}$ is the market index on day $t$, and $\mathrm{I}_{t-1}$ is the market index on day $t-1$. For a sample of $\mathrm{N}$ securities the average $\mathrm{MAAR}_{i t}$ for the day $t$ is calculated by:

\section{$\overline{M A A R}_{t}=(1 / N) \sum_{i=1}^{N} M A A R_{i t} \quad \ldots .3$}

Where, $\mathrm{t}=-30,-29 \ldots \ldots \ldots+30$

After computing the abnormal returns for all securities in the sample, the cumulative abnormal returns (CAR) are calculated to measure the total returns over the concerned period. The CAR is computed using the following formula:

$$
\overline{C A R_{(l, j)}}=\sum_{t=l}^{j} \overline{M^{2} A R_{t}} \quad \ldots \ldots 4
$$

Where, $\overline{C A R_{(l, j)}}$ is the cumulative abnormal return from day $l$ to day $j$, which refers to the starting day -30 till the day up to which the CAR is calculated, here ranging from -30 to +30 surrounding by the announcement day.

\subsubsection{Testing of ABnormal Returns}

For testing the significance of abnormal returns three types of t-tests are used (Saens, Sandoval 2005), namely the standardized t-test, cross-sectional t-test and the portfolio t-test. However, the study conducted by Saens and Sandoval on the Chilean Stock Market using daily stock returns concluded that the use of standardized t-test is always more effective in detecting the presence of abnormal return than the cross-sectional and the portfolio $t-$ tests, even in the presence of non-normality of security returns.

The earlier writers such as Patell (1976), Brown and Warners (1985) and Dyckman et al. (1984) studied randomly selected securities of New York Stock Exchange (NYSE) and American Stock Exchange (AMEX). They concluded that the non-normality problem does not have serious impact on the power of the short-run event study method and that the common parametric t-test may be used to test the null hypothesis.

Therefore, even in the presence of non-normality, as our sample were drawn from across different industries with different event dates and categories of securities, we felt it would be appropriate to use the test statistics specified 
by Saens and Sandoval (2005), and Odabasi (1998) on an emerging capital market in Latin America, namely the Chilean Stock Exchange. In this study the standardized ttest has been used to test the presence of abnormal returns in day 0 .

Under the standardized t-test each abnormal security return is normalized by the estimation period standard deviation using the following steps:

\section{$M A A R_{i t}$ \\ $S A R_{i t}=\overline{S D\left(M A A R_{i t}\right)}$} .......5

Where, $S A R_{i t}$ is the standardized abnormal return, $M A A R_{i t}$ is as the market adjusted abnormal return as specified under equation 2 , and $S D\left(M A A R_{i t}\right)$ is the standard deviation of each abnormal return which is calculated as:

$\left.S D\left(M A A R_{i t}\right)=\sqrt{\left(\frac{1}{T-1}\right.} \sum_{t=1}^{T} M A A R_{i t}^{2}\right) \ldots 6$

Where, $T$ is the number of days in the estimation period for security $i$.

The average standardized abnormal return, $\overline{S A R_{t}}$ and the average cumulative standardized abnormal return, $\overline{C S A R_{(i, j)}}$ for $\mathrm{N}$ sample are computed by:

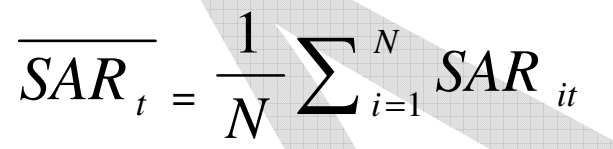
.......7

and

$$
\overline{\operatorname{CSAR}_{(i, j)}}=\frac{1}{N} \sum_{i=1}^{N} \operatorname{CSAR}_{i,(l, j)} \ldots 8
$$

The standardized t-test for abnormal return on the event day will then be:

$$
T_{(t, t)}=\overline{\operatorname{SAR}_{t}}(\sqrt{N})
$$

and

$$
T_{(l, j)}=\overline{\operatorname{CSAR}_{(l, j)}}(\sqrt{N}) \ldots \ldots 10
$$

The test statistic $T_{(t, t)}$ is used to test if the expected value of the average standard abnormal returns on the event day is different from zero. Similarly, the test statistic $T_{(l, j)}$ is used to test if the expected value of the average cumulative standardized abnormal return is different from zero over the period from 1 to $\mathrm{j}$.

The above standardized t-tests assume that the individual returns are cross-sectionally independent and identically distributed. By the Central Limit Theorem, the standardized t-test converges to unit normal under the null hypothesis of no abnormal return. For our analysis a $90 \%$ level of significance will be used for accepting (or rejecting the null hypothesis).

\section{ANALYSIS AND FINDINGS}

\subsection{Comparing Market Adjusted Abnormal RETURNS (MAAR)}

Comparison between the market adjusted average abnormal returns (MAAR) for stock dividend and the MAAR for the cash dividend is shown with their respective $t$ values with $n-1$ degrees of freedom $(n=16$ for stock and $n=23$ for cash). The findings have been reported under the table-1. This indicates that the market adjusted average abnormal returns attributed solely to the dividend announcement day is statistically insignificant for both stock and cash dividends. Thus, it is evidence that there are no differences in the impact of cash or stock dividend as far as the announcement day is concerned.

However, the significant negative returns for equity dividend prior to the announcement day (such as day-23, 18 , and -13) indicate speculative nature of the investors' behavior. As it is with the nature of weak form efficient market to predict the returns around an up coming event, the rumors and hearsay dominates the market. It is also possible that the news has been leaked out earlier resulting in the negative effect of the event. In such a case the negative returns associated prior to the announcement justify that the speculators are in action with negative news about the announcement.

On the other hand positive returns for stock dividends are reported after the announcement, (such as day 9, 12, 22) indicating positive attitude during the post announcement period. The positive returns could be attributed to the lag between the announcement day and the record day. As the record day becomes nearer, the stock indicates some positive returns, though the length of the lag may vary for A, B or Z categories of companies as far as the DSE is concerned. Therefore, the investors in general shows more positive attitude towards stock dividends rather than cash dividend.

As far as cash dividend is concerned, there is no significant returns exist as a result of cash dividend declaration. Furthermore, the negative MAAR (though not statistically significant) on the declaration day may indicate the investors unfulfilled expectation for stock dividend.

Table-1: Comparison between markets adjusted abnormal turn of stock and cash dividend. 


\begin{tabular}{|c|c|c|c|c|}
\hline Day & $\begin{array}{c}\text { Equity } \\
\text { MAAR(\%) }\end{array}$ & T values & $\begin{array}{c}\text { Cash } \\
\text { MAAR(\%) }\end{array}$ & T values \\
\hline-30 & 0.91 & 1.34239 & 0.13 & 0.001038 \\
\hline-29 & 0.15 & 0.28173 & -0.07 & -0.000580 \\
\hline-28 & -0.55 & -1.03362 & -0.06 & -0.000480 \\
\hline-27 & 0.09 & 0.23492 & 0.20 & 0.001808 \\
\hline-26 & -0.53 & -0.76085 & -0.58 & -0.005342 \\
\hline-25 & -0.13 & -0.16415 & -0.34 & -0.003215 \\
\hline-24 & 0.05 & 0.12580 & $\begin{array}{l}-0.31 \\
\end{array}$ & -0.003100 \\
\hline-23 & -0.85 & $-1.90856^{*}$ & 0.45 & 0.004729 \\
\hline-22 & 0.07 & 0.09838 & -0.52 & -0.005659 \\
\hline-21 & -0.35 & -0.55624 & 0.02 & 0.000283 \\
\hline-20 & 0.19 & 0.38038 & 0.35 & 0.004206 \\
\hline-19 & -0.34 & -0.79178 & 0.48 & 0.006067 \\
\hline-18 & -1.42 & $-2.63302^{*}$ & 0.35 & 0.004714 \\
\hline-17 & -0.34 & -0.63388 & -0.43 & -0.006110 \\
\hline-16 & -0.12 & -0.23324 & 0.22 & 0.003335 \\
\hline-15 & 0.87 & 1.09192 & -0.76 & -0.012106 \\
\hline-14 & -0.51 & -1.26681 & 0.23 & 0.003948 \\
\hline-13 & -0.88 & $-2.29192^{*}$ & -0.38 & -0.007005 \\
\hline-12 & -1.14 & -1.52072 & -0.45 & -0.009041 \\
\hline-11 & -0.75 & -1.18975 & 0.06 & 0.001239 \\
\hline-10 & 0.09 & 0.24291 & -0.10 & -0.002429 \\
\hline-9 & 0.73 & 1.43678 & -0.47 & -0.012526 \\
\hline-8 & -0.63 & -1.51176 & 1.01 & 0.030237 \\
\hline-7 & 0.67 & 0.82457 & 1.71 & 0.058314 \\
\hline-6 & 0.42 & 0.98826 & 0.34 & 0.013474 \\
\hline-5 & 1.08 & 1.51777 & -0.05 & -0.002224 \\
\hline-4 & 0.66 & 0.97474 & -0.34 & -0.020562 \\
\hline-3 & 0.15 & 0.25224 & 0.27 & 0.021737 \\
\hline-2 & 0.52 & 0.64917 & 0.56 & 0.066458 \\
\hline-1 & 0.78 & 1.45023 & -0.12 & -0.029760 \\
\hline 0 & 0.22 & 0.30349 & -1.33 & -1.305348 \\
\hline 1 & 2.29 & 1.46509 & -1.63 & -0.375755 \\
\hline 2 & 0.64 & 1.02685 & -0.13 & -0.015769 \\
\hline 3 & 0.81 & 1.33136 & -0.04 & -0.003457 \\
\hline 4 & -0.08 & -0.10835 & 0.46 & 0.027412 \\
\hline 5 & 0.04 & 0.10945 & -0.08 & -0.003897 \\
\hline 6 & 0.20 & 0.60070 & 0.79 & 0.031444 \\
\hline 7 & 0.13 & 0.30090 & 0.40 & 0.013682 \\
\hline 8 & -0.01 & -0.04862 & -0.01 & -0.000421 \\
\hline 9 & 0.69 & $1.82802^{*}$ & -0.38 & -0.010214 \\
\hline 10 & -0.11 & -0.34011 & 0.96 & 0.023055 \\
\hline 11 & 0.18 & 0.52347 & -1.00 & -0.021827 \\
\hline 12 & 1.72 & $2.77549^{*}$ & -0.03 & -0.000637 \\
\hline 13 & -1.49 & -0.90130 & -0.17 & -0.003124 \\
\hline 14 & -0.37 & -0.65645 & -0.84 & -0.014436 \\
\hline 15 & -0.04 & -0.08565 & 0.11 & 0.001786 \\
\hline 16 & 0.90 & 1.54361 & -0.34 & -0.005080 \\
\hline 17 & 0.72 & 1.44729 & -0.37 & -0.005287 \\
\hline 18 & -1.46 & -1.10710 & -0.56 & -0.007487 \\
\hline 19 & -1.47 & -0.81539 & 0.74 & 0.009339 \\
\hline 20 & -2.13 & -1.00914 & -0.01 & -0.000096 \\
\hline 21 & 0.33 & 0.37747 & 0.09 & 0.001084 \\
\hline 22 & 3.08 & $2.01362^{*}$ & -0.14 & -0.001544 \\
\hline 23 & 0.09 & 0.14523 & 0.39 & 0.004051 \\
\hline 24 & -0.34 & -0.44656 & 0.75 & 0.007536 \\
\hline 25 & 0.88 & 1.64175 & 0.85 & 0.008179 \\
\hline 26 & -0.52 & -0.35541 & 0.16 & 0.001509 \\
\hline 27 & 0.45 & 0.49382 & 0.79 & 0.007026 \\
\hline 28 & -1.62 & -1.72022 & 0.65 & 0.005604 \\
\hline 29 & 0.56 & 1.28370 & 1.11 & 0.009174 \\
\hline 30 & -0.16 & -0.13377 & -0.07 & -0.000580 \\
\hline
\end{tabular}

* indicates significant $t$ values at $90 \%$ level of confidence and

** indicates significant $t$ values at $99 \%$ level.

A side by side presentation of the graphs of MAAR for both the cash and stock dividend would represent a clear picture for us to analyze. The following figure shows how they differ from each other surrounding the announcement date.

\section{Insert Figure 1 here}

\subsection{Comparison between Cumulative AdJUSTEd ABNoRMAL RETURNS (CAAR) OF STOCK AND CASH DIVIDENDS}

The behavior of CAAR indicates a surprise finding with regards to the stock dividends. Continuous negative returns have been reported since 23rd day prior to the announcement. This continues even up to the 2 days after the announcement day. It is further evidenced that if anybody holds a share up to the announcement day, he/she will incur a significant loss of $0.90 \%$. However, the market bounces back with positive returns immediately and significant positive returns are reported for 2 days immediate after the announcement and again continue to with positive returns from the 9th working day and beyond. The highest CAAR of $5.61 \%$ is reported on the 12th day after the announcement, which also coincides with the significant positive MAAR of $1.72 \%$ on that day, as the record day for entitlement of the dividend approaches nearer. The above findings would like to conclude that the record day plays a very important indicator for realizing the abnormal returns for stock dividend.

On the other hand, for cash dividend, though positive returns exist immediately prior to the announcement date, they are statistically insignificant. Once the rumor and speculation regarding the dividend announcement subsides, immediately after the declaration day statistically insignificant negative returns are reported.

Table-2: Cumulative average abnormal return between stock and Cash Dividend.

\begin{tabular}{|r|r|r|r|r|}
\hline Day & $\begin{array}{c}\text { Equity } \\
\text { CAAR (\%) }\end{array}$ & \multicolumn{1}{c|}{ T values } & \multicolumn{1}{c|}{$\begin{array}{c}\text { Cash } \\
\text { CAAR(\%) }\end{array}$} & \multicolumn{1}{l|}{ T values } \\
\hline-30 & 0.91 & 1.342391 & 0.13 & 0.001038 \\
\hline-29 & 1.05 & 1.624124 & 0.06 & 0.000458 \\
\hline-28 & 0.51 & 0.590505 & 0.00 & -0.000022 \\
\hline-27 & 0.60 & 0.825422 & 0.21 & 0.001786 \\
\hline-26 & 0.07 & 0.064569 & -0.37 & -0.003556 \\
\hline-25 & -0.06 & -0.099576 & -0.71 & -0.006771 \\
\hline-24 & -0.02 & 0.026222 & -1.02 & -0.009871 \\
\hline-23 & -0.87 & $-1.882342^{*}$ & -0.56 & -0.005142 \\
\hline-22 & -0.80 & $-1.783963^{*}$ & -1.08 & -0.010801 \\
\hline-21 & -1.15 & $-2.340204^{*}$ & -1.06 & -0.010518 \\
\hline-20 & -0.96 & $-1.959822^{*}$ & -0.71 & -0.006311 \\
\hline-19 & -1.30 & $-2.751598^{*}$ & -0.23 & -0.000244 \\
\hline-18 & -2.72 & $-5.384617^{* *}$ & 0.13 & 0.004469 \\
\hline
\end{tabular}




\begin{tabular}{|c|c|c|c|c|}
\hline-17 & -3.06 & $-6.018497^{* *}$ & -0.31 & -0.001641 \\
\hline-16 & -3.18 & $-6.251740^{* *}$ & -0.08 & 0.001694 \\
\hline-15 & -2.31 & $-5.159823^{* *}$ & -0.84 & -0.010412 \\
\hline-14 & -2.82 & $-6.426634^{* *}$ & -0.61 & -0.006464 \\
\hline-13 & -3.70 & $-8.718555^{* *}$ & -0.99 & -0.013469 \\
\hline-12 & -4.84 & $-10.239277^{* *}$ & -1.44 & -0.022510 \\
\hline-11 & -5.58 & $-11.429029^{* *}$ & -1.38 & -0.021271 \\
\hline-10 & -5.50 & $-11.186119^{* *}$ & -1.49 & -0.023700 \\
\hline-9 & -4.77 & $-9.749337^{* *}$ & -1.96 & -0.036226 \\
\hline-8 & -5.40 & $-11.261101^{* *}$ & -0.95 & -0.005989 \\
\hline-7 & -4.73 & $-10.436534^{\star *}$ & 0.76 & 0.052325 \\
\hline-6 & -4.31 & $-9.448279^{* *}$ & 1.10 & 0.065798 \\
\hline-5 & -3.23 & $-7.930510^{* *}$ & 1.05 & 0.063574 \\
\hline-4 & -2.57 & $-6.955767^{* *}$ & 0.71 & 0.043012 \\
\hline-3 & -2.42 & $-6.703523^{* *}$ & 0.98 & 0.064749 \\
\hline-2 & -1.90 & $-6.054356^{* *}$ & 1.54 & 0.131207 \\
\hline-1 & -1.12 & $-4.604128^{* *}$ & 1.42 & 0.101447 \\
\hline 0 & -0.90 & $-4.300641^{* *}$ & 0.08 & -1.203902 \\
\hline 1 & 1.40 & $-2.835549^{*}$ & -1.55 & -1.579657 \\
\hline 2 & 2.04 & $-1.808703^{*}$ & -1.68 & -1.595426 \\
\hline 3 & 2.85 & -0.477344 & -1.73 & -1.598882 \\
\hline 4 & 2.77 & -0.585690 & -1.27 & -1.571471 \\
\hline 5 & 2.82 & -0.476236 & -1.35 & -1.575367 \\
\hline 6 & 3.02 & 0.124466 & -0.57 & -1.543923 \\
\hline 7 & 3.15 & 0.425366 & -0.17 & -1.530241 \\
\hline 8 & 3.13 & 0.376747 & -0.18 & -1.530663 \\
\hline 9 & 3.82 & $2.204767^{*}$ & -0.56 & -1.540877 \\
\hline 10 & 3.72 & $1.864657^{*}$ & 0.40 & -1.517822 \\
\hline 11 & 3.89 & $2.388128^{*}$ & -0.61 & -1.539649 \\
\hline 12 & 5.61 & $5.163619^{* *}$ & -0.64 & -1.540285 \\
\hline 13 & 4.12 & $4.262323^{* *}$ & -0.81 & -1.543409 \\
\hline 14 & 3.75 & $3.605876^{* *}$ & -1.65 & -1.557845 \\
\hline 15 & 3.72 & $3.520228^{* *}$ & -1.54 & -1.556059 \\
\hline 16 & 4.61 & $5.063839 * *$ & -1.88 & -1.561139 \\
\hline 17 & 5.33 & $6.511133^{* *}$ & -2.25 & -1.566426 \\
\hline 18 & 3.87 & $5.404031^{* *}$ & -2.81 & -1.573913 \\
\hline 19 & 2.40 & $4.588643^{* *}$ & -2.07 & -1.564574 \\
\hline 20 & 0.28 & $3.579501^{* *}$ & -2.08 & -1.564670 \\
\hline 21 & 0.61 & $3.956971^{\text {** }}$ & -1.99 & -1.563586 \\
\hline 22 & 3.69 & $5.970589 * *$ & -2.13 & -1.565131 \\
\hline 23 & 3.78 & $6.115819^{* *}$ & -1.74 & -1.561080 \\
\hline 24 & 3.44 & $5.669254^{* *}$ & -0.99 & -1.553544 \\
\hline 25 & 4.32 & $7.311000^{* *}$ & -0.13 & -1.545364 \\
\hline 26 & 3.80 & $6.955593^{* *}$ & 0.03 & -1.543855 \\
\hline 27 & 4.25 & $7.449409^{* *}$ & 0.82 & -1.536829 \\
\hline 28 & 2.63 & $5.729193^{* *}$ & 1.47 & -1.531225 \\
\hline 29 & 3.19 & $7.012898^{* *}$ & 2.58 & -1.522051 \\
\hline 30 & 3.02 & $6.879133^{* *}$ & 2.51 & -1.522631 \\
\hline
\end{tabular}

* indicates significant $t$ values at $90 \%$ level of confidence and

** indicates significant $t$ values at $99 \%$ level.

A side by side representation of the CAAR under the same graph indicates the contrasting scenario for the returns attributable to cash and stock dividends as presented under the figure 2 .

\section{Insert Figure 2 here}

\section{CONCLUSION AND POLICY IMPLICATION}

This study intended to analyze if declaration of stock dividends has more impacts on the share prices than that of the cash dividends. It used event study method to identify if there is any gain solely attributable to the dividend announcement using the Market Adjusted Average Abnormal Returns (MAAR) and Cumulative Average Abnormal Returns (CAAR). Using standardized $t$ test and at $90 \%$ confidence level this study found that there is no evidence of abnormal returns on the declaration day for both stock and cash dividends. However, significant negative returns for stock dividend have been observed prior to the announcement day (such as day-23,-18, and 13) which indicates speculative nature of the investors' behavior in DSE. Positive returns for stock dividends after the announcement, (such as day 9, 12, 22) could be attributed to the lag between the announcement day and the record day. Therefore, the investors in general shows more positive attitude towards stock dividends rather than cash dividend as far MAAR is concerned.

As far as the CAAR is concerned continuous negative returns are observed since 23 rd day prior to the announcement till the 2 days after the announcement day and if anybody holds a share up to the announcement day, he/she will incur a significant loss of $0.90 \%$. However, it is surprising that the market provides cumulative positive returns from the 9th working day onward for the selected event window. The highest CAAR of $5.61 \%$ is reported on the 12th day after the announcement, which also coincides with the significant positive MAAR of $1.72 \%$. The above findings would like to conclude that the record day plays a very important indicator for realizing the abnormal returns for stock dividend. As far as CAAR for cash dividend is concerned no significant abnormal returns are found under the present analysis.

The above finding proposes an interesting policy to the investors who are willing to invest with the companies listed under the DSE. It suggests that the investors should hold their shares after the announcement when the companies declare stock dividends and sell them on 12 th working day for maximizing their abnormal returns and if the companies declare cash dividends the investors would not earn any abnormal returns from their investment.

\section{REFERENCES}

[1] Baker, H.K. and A.L.Philips, (1993), "Why companies issue stock dividends", Financial Practice \& Education" 3, 29-37.

[2] Banker, R.D., S. Das, and S. M. Datar, (1993), “Complementary of prior accounting information: The case of stock dividend announcements," The Accounting Review, 68, $28-47$.

[3] Baker, H.K. and A.L.Philips, and G.E. Powell, (1995), “The Stock distribution puzzle: A Synthesis of the literature on stock splits and stock dividends", Financial Practice \& Education, Spring/ Summer, 24-27.

[4] Black Fischer, (1976), "The dividend puzzles", Journal of portfolio Management, 2:5-8.

[5] Bodie, Z., Kane, A., \& Marcus, A. J. (2005), Investment, McGraw-Hill, Boston, 6th Ed.

[6] Bowman, R. G. (1983), "Understanding and Conducting Event Studies", Journal of Business Finance and Accounting, Vol. 10, issue 4, pp. 561-584. 
[7] Brown, S. J., Warner, J. B. (1980), "Measuring Security Price Performance", Journal of Financial Economics, Vol. 8, pp. 205-258.

[8] Chen, G.M.Firth, and N. Gao, (2002), "The information content of concurrently announced Earnings: An investigation of the Chinese Stock Market", Journal of International Financial Management and Accounting, 13 (2), 101-124.

[9] Chottiner, S. and A. Young, (1971), "A test of the AICPA differentiation between stock dividends and sock splits", Journal of Accounting Research 9, 367-374.

[10] Conroy, R.M.K.M. Eades, and R.S. Harris, (2000), "A test of the relative pricing effects of dividends and earnings: Evidence from simultaneous announcement in Japan", Journal of Finance 55, 1199-1227.

[11] Eisemann, P.C. and E. A. Moses, (1978), “Stock dividends: Management's view." Financial Analysts Journal 31, 77-80.

[12] Fung, H G. and W.K. Leung, (2001), "Financial liberalization and corporate governance in china.", International Journal of Business, 2 (2), 331.

[13] Foster, T. W. III and D. Vickrey, (1978), “The information content of stock dividend announcements," The Accounting Review 53, 360-370.

[14] Faccio, M.L.Lang, and L. Young, (2001), "Dividends and expropriation", American Economic Review, 91, 54-78.

[15] Ghosh, C. and J. R. Woolridge, (1988), "An analysis of shareholder reaction to dividend cuts and omission," Journal of Financial Research 11, 281-294.

[16] Huang, A.G. and H.G. fung, (2004), "Stock ownership segmentation, floatability, and constraints on investment banking in china.", China and world Economy, 12 (2), 66-78.

[17] Kalay, A. and U. Loewenstein, (1985), "Predictable events and excess returns: the case of dividend announcements," Journal of Financial
Economics 14, 149-175.

[18] Kritzman, M. P. (1994), “What Practitioners Need to Know about Event Studies", Financial Analysts Journal, vol.50, pp. 17-20

[19] MacKinlay, A. C. (1997), "Event Studies in Economics and Finance", Journal of Financial and Quantitative Analysis, Vol 27 No 1, March 1992.

[20] Merton H Miller, Franco Modigliani., (1961), "Dividend policy, growth, and the valuation of shares.", Journal of Business, 34:411-33.

[21] Miller, M. and F. Modigliani, (1961), "Dividend Policy, Growth and The Valuation of Shares" Journal of Business, 34, 411-433.

[22] Odabasi, A., (1998), "Security Returns' Reactions To Earnings Announcements: A Case Study On The Istanbul Stock Exchange", Bogazice Journal: Review of Social, Economic and Administrative Studies, vol. 12, No. 2, pp. 3-19

[23] Patell M. J. (1976), “Corporate Forecasts of Earnings per Share and Stock Price Behavior: Empirical Test", Journal of Accounting Research, Vol. 14, No.2 (Autumn, 1976), pp. 246-276

[24] Rahman, M, L., and Amin, M, R., (2009), "Effects of Dividend Declaration on the Security Price Performance Using Dhaka Stock Exchange Limited: Event Study Method", Journal of Business and Technology (Dhaka), Vol. iv, issue i, pp. 30-47.

[25] Saens, R., Sandoval, E. (2005), “Measuring Security Price Performance Using Chilean Daily Stock Returns: The Event Study Method", Cuadernos de Economia, Vol. 42, issue 126, pp. 307-328.

[26] Wei Chen, Xing Liu, Yuanxin Yang., (1999), “An empirical study on the signaling effect of dividend policy in shanghais stock market". Chinese Journal of Management Science; 7(3).

[27] Yu Qiao, Yin Chen. (2001), "Dividend policy and fluctuation of stock market in Chinese companies". Economic Research; 4. 


\section{Figure 1}

\section{MAAR for Equity and Cash Dividend}

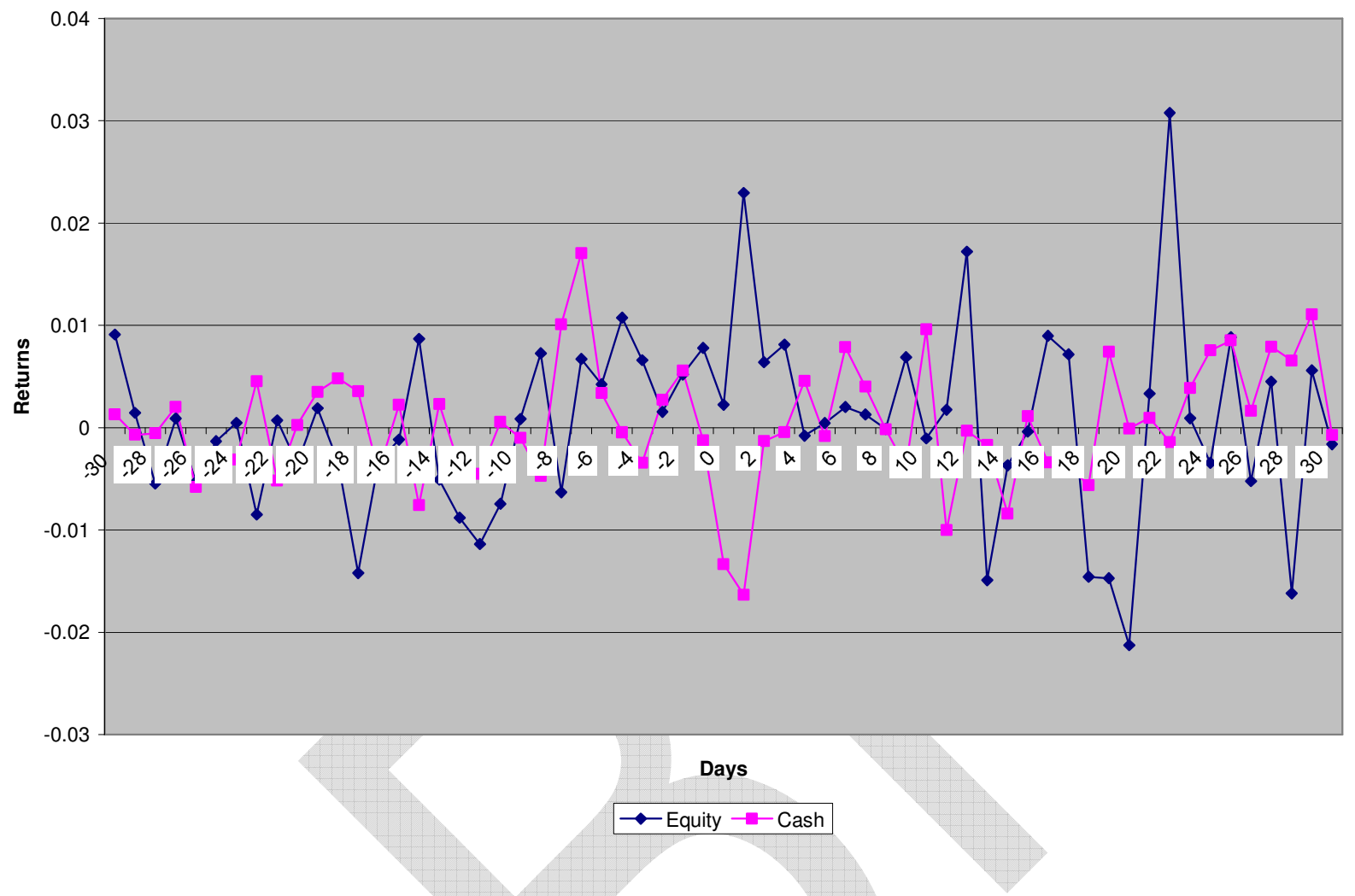

Figure 2

Comparison between CAAR for Equity and Cash Dividend

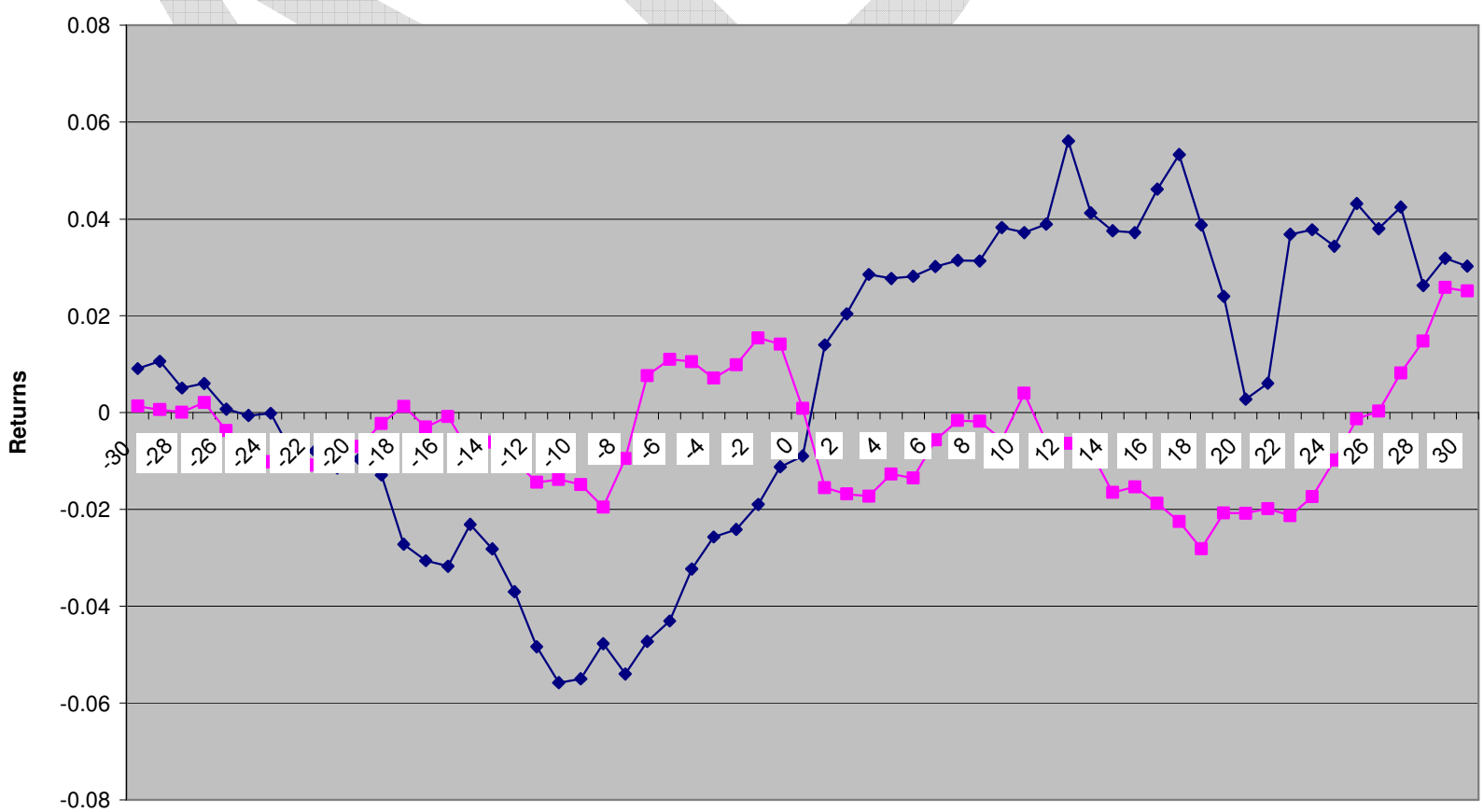

Days

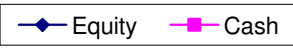

